\title{
ЗД-60 \\ ИДЕНТИФИКАЦИЯ ИСТОЧНИКА НЕФТИ И ИССЛЕДОВАНИЕ ВАРИАЦИЙ СОСТАВА ИЗВЛЕКАЕМОЙ НЕФТИ ПО РЕЗУЛЬТАТАМ АНАЛИЗА ИЗОМЕРНОГО СОСТАВА УГЛЕВОДОРОДОВ
}

Туров Ю.П., Гузняева М.Ю.

БУ ВО Сургутский государственный университет, Сургут, Россия

yuri_tom@rambler.ru

DOI: 10.26902/ASFE-11_198

Необходимость идентификации источника и происхождения конкретного образца нефти возникает при решении многих научных и практических задач. Результаты химикоаналитического контроля нефтяного загрязнения компонентов природной среды позволяют установить источник загрязнения и разработать реабилитационные и юридические мероприятия по снижению последствий и компенсации ущербов. Квалифицированное геохимическое сопровождение процессов эксплуатации нефтяных месторождений по результатам анализа материального состава извлекаемой нефти позволяет оптимизировать режимы работы добывающих скважин и повысить коэффициент извлечения нефти, снижая суммарные и удельные затраты на добычу сырья. В то же время известно, что под «образцом нефти» конкретного месторождения понимают усредненную пробу нефти, представляющую собой смесь нефтяных флюидов, извлекаемых из разных добывающих скважин.

В данном сообщении приведены оценки вариаций состава образцов нефти из разных скважин одного месторождения и примеры идентификации образцов по результатам анализа изомерного и гомологического состава насыщенных и ароматических углеводородов в образцах нефти из месторождений ХМАО.

Показано, что по изомерному составу парафинов и алкилнафталинов, определенному методами хроматомасс-спектрометрии, и по их относительным содержаниям в образце можно надежно идентифицировать продуктивный нефтеносный пласт, из которого получен конкретный образец нефти. Использование информации об изомерном составе фенантренов, дибензотиофенов и других классов ароматических веществ (аценафтенов, флуоренов, флуорантенов) позволяет в большинстве случаев дифференцировать образцы по принадлежности их к определенной продуктивной скважине, из которой они были отобраны. Сопоставление состава различных образцов проведено с использованием так называемых геохимических параметров, которые рассчитывают по относительным содержаниям изомеров и используют в органической геохимии для идентификации и сопоставления состава

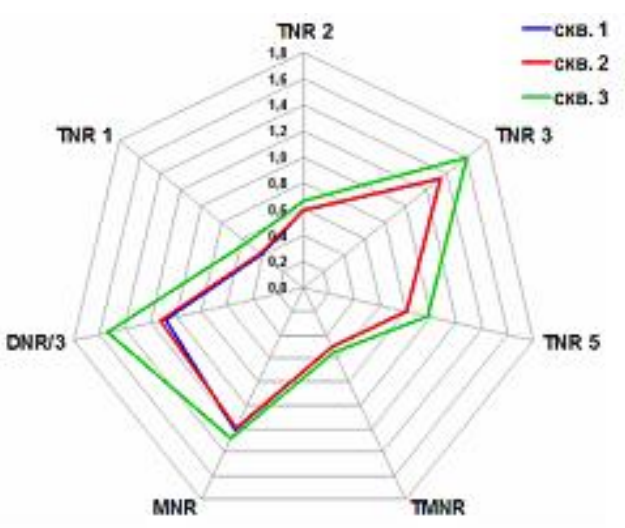
геологических образцов нефти и рассеянного органического вещества пород. На рисунке приведен для иллюстрации пример сравнения состава нафталинов в образцах нефти из трех скважин одного многопластового месторождения. Как следует из рисунка, состав нефти, извлекаемой из скважин №o 1 и 2, существенно отличается от извлекаемой из скважины № 3, что соответствует геологическим данным о том, что эти три скважины работают на два разных продуктивных горизонта.

Метилнафталиновый индекс: $M N R=2-м н$ / 1-мн; Диметилнафталиновый индекс: $D N R=(2,6-\partial м н+2,7-$ дмн)/1,5-дмн; Триметилнафталиновые индексы: TNR 1=2,3,6-тмн/(1,4,6-тмн +1,3,5-тмн); TNR 2=(1,3,7-тмн +2,3,6-тмн $) /(1,3,5-m м н+1,4,6-m м н+1,3,6-m м н)$;

TNR 3=1,3,6-тмн /1,2,5-тмн;

TNR 5=1,3,7-тмн /(1,4,6-тмн +1,3,5-тмн); TMNR=1,3,7-тмн /(1,3,7-тмн +1,2,5-тмн); -мн, -дмн и -тмн-метилнафталины, диметилнафталины и триметилнафталинь соответственно 